\title{
Comparative evaluation of the nutritional, phytochemical and microbiological quality of three pepper varieties
}

\section{Christine Emmanuel-Ikpeme*, Peters Henry, Orim Augustine Okiri}

Biochemistry Department, University of Calabar, Cross River State, Nigeria

Email address:

amakaikpeme@gmail.com (C. Emmanuel-Ikpeme)

\section{To cite this article:}

Christine Emmanuel-Ikpeme, Peters Henry, Orim Augustine Okiri. Comparative Evaluation of the Nutritional, Phytochemical and Microbiological Quality of Three Pepper Varieties. Journal of Food and Nutrition Sciences. Vol. 2, No. 3, 2014, pp. 74-80.

doi: 10.11648/j.jfns.20140203.15

\begin{abstract}
The study investigated the comparative evaluation of nutritional, phytochemical, and microbiological quality of three pepper varieties (Capsicum annuum, Capsicum genus, and Capsicum frutescens). Three pepper varieties were purchased fresh from local market in Calabar, Cross River State. The samples were washed with distilled water and thinly sliced, (diameter of $1.0 \pm 0.1 \mathrm{~cm}$ and thickness of $3-4 \mathrm{~mm}$ ), and then treated with chlorine concentrated solution. These samples were oven dried at temperature of $60^{\circ} \mathrm{C}$ for 24 hours. The samples were ground with a woring blender and stored in air-tight container. The result of the analysis showed that the proximate composition of Capsicum genus was significantly $(\mathrm{p}<0.05)$ higher than Capsicum annuum and Capsicum frutescens in moisture and carbohydrate contents. Capsicum annuum was significantly $(\mathrm{p}<0.05)$ higher than Capsicum genus and Capsicum frutescens in fat, insoluble and soluble fibre contents. Capsicum frutescens was significantly $(\mathrm{p}<0.05)$ higher than Capsicum annuum and Capsicum genus in protein and ash contents. Vitamin composition showed that Capsicum annuum was significantly $(\mathrm{p}<0.05)$ higher than Capsicum genus and Capsicum frutescens in vitamin $\mathrm{C}$, vitamin $\mathrm{A}$, vitamin $\mathrm{E}$, niacin, vitamin $\mathrm{B}_{6}$, folic acid, and vitamin $\mathrm{K}$. Mineral composition showed that Capsicum annuum was significantly $(\mathrm{p}<0.05)$ higher Capsicum frutescens and Capsicum genus in calcium, sodium, magnesium, phosphorus, copper, zinc, and nickel contents. Capsicum genus was significantly $(\mathrm{p}<0.05)$ higher than Capsicum annuum and Capsicum frutescens in potassium, iron and cobalt contents. Phytochemical composition showed that Capsicum annuum was significantly $(\mathrm{p}<0.05)$ higher than Capsicum genus and Capsicum frutescens in tannins, flavonoid, saponin, terpenoid, and carotenoid contents. Capsicum genus was significantly $(\mathrm{p}<0.05)$ higher than Capsicum annuum and Capsicum frutescens in alkaloid, phenolic compound, glycoside, and limonoid contents. Capsicum frutescens was significantly $(\mathrm{p}<0.05)$ higher than Capsicum genus and Capsicum annuum in anthraquinone contents. Aspergillus spp and Staphylococcus spp in Capsicum annum, Capsicum genus, and Capsicum frutescens were less than $10 \%$ and $100 \%$. Escherichia coli and salmonella in these pepper varieties were not detected or absent. The result of this analysis revealed that the three pepper varieties have high nutritive value, medicinal value and can be used to remediate diseases and sustain health.
\end{abstract}

Keywords: Pepper, Phytochemical, Proximate Composition, Calcium, Sodium

\section{Introduction}

Pepper, chili, or chili belongs to the Solanaceae family genus Capsicum and is closely related to tomato, eggplant, potato and tobacco. The genus Capsicum represents a diverse plant group and includes twenty seven species; five domesticated and twenty two un-domesticated (Bosland, 1993). Capsicum annuum, C. frutescens, Capsicum genus, Capsicum baccatum and Capsicum pubescens are considered domesticated species of peppers. Peppers are quite diverse and may be classified by the trade according to the end use. Peppers grown for their characteristics hot flavor are of genus Capsicum, Capsicum annuum principally and Capsicum frutescens to a lesser extent.

Red Pepper is an important agricultural crop, not only because of its economic importance, but also due to nutritional and medicinal value. These are the excellent source of natural colors and antioxidant compounds (Howard et al., 2000). A wide spectrum of antioxidant vitamins, carotenoids, and phenolic compounds are present in pepper. The intake of these compounds in food is an important health-protecting factor by prevention of 
widespread human diseases. As consumption continues to increase, red peppers could provide important amounts of nutritional antioxidants to the human diet (Marin et al., 2004).

Nigeria like other tropical countries has abundance of pepper varieties that grow all year round. Pepper occupies an important place in the diets of Nigerians. Long chili pepper (Capsicum genus), Drum pepper (Capsicum annuum), Small chili pepper (Capsicum frutescens) are among the pepper varieties consumed in Nigeria. Their nutritional contribution has not been widely exploited. Nutritional information on these varieties of pepper will be useful for the nutritional education of the public as a means to improve the nutritional status of the population. In this study, we determined the nutritional, phytochemical and microbiological quality of these pepper consumed in Nigeria.

\section{Materials and Methods}

\subsection{Preparation of Sample}

Three pepper varieties (Capsicum annuum, Capsicum genus, and Capsicum frutescens) were purchased fresh from the local market in Calabar, Cross River State. The samples were washed with distilled water and thinly sliced, and then treated with chlorine concentrated solution. These samples were oven dried at temperature of $60^{\circ} \mathrm{C}$ for 24 hours. The samples were ground with a blender (Model No. $205)$ and stored in air-tight container. Each sample (100g) was weighed and extracted with methanol which was used for the analysis.

\subsection{Determination of Proximate Analyses}

Moisture, protein, fat, ash and crude fiber contents were determined by AOAC method (1990) while carbohydrate content was determined by difference: 100- (\%Moisture $+\%$ Ash $+\%$ Protein $+\%$ Fat $+\%$ Crude fiber $)$. The moisture content was determined by hot air oven method at $105^{\circ} \mathrm{C}$. The Macro Kjeldahl method was used for the determination of protein content. The fat content was determined by extracting $2 \mathrm{~g}$ of sample with petroleum ether (boiling point of $40^{\circ} \mathrm{C}$ to $60^{\circ} \mathrm{C}$ ) using soxhlet extraction method. Ash content was determined by weighing $2 \mathrm{~g}$ of dry sample into a tarred porcelain crucible which was incinerated at $550^{\circ} \mathrm{C}$ in an ash muffle furnace until ash was obtained. The crude fiber was determined by exhaustive extraction of soluble substances in sample using $1.25 \% \mathrm{H}_{2} \mathrm{SO}_{4}$ acid and $1.25 \%$ $\mathrm{NAOH}$ solution after the residue was ashed and the loss in weight was recorded as crude fiber.

\subsection{Determination of Mineral and Vitamin Elements}

The method of AOAC (1990) was used to determine minerals. The samples were wet digested with concentrated nitric and percholoric acids. The minerals calcium $(\mathrm{Ca})$ and magnesium $(\mathrm{Mg})$ were determined by atomic absorption spectrophotometer (Model 3030 Perkin Elmer, Nortwalk, USA). Potassium (K) and Sodium (Na) were determined with the aid of corning 400 flame photometer according to the method of Oyeleke (1984). Phosphorus was determined using spectrophotometer (JASCO V-630) followed by the method as described by Pearson (1976). The concentration of phosphorus was determined through the measurement of the yellow phosphor vanado-molybdate complex using Cecil Digital Spectrophotometer series. Vitamin A was determined spectrophotometrically using the method adopted from IVACG (1992). Vitamin C and other trace vitamins (Folic acid, Vitamin $\mathrm{B}_{6}$, Niacin) were determined using AOAC 1990 method.

\subsection{Determination of Phytochemicals}

Alkaloid was determined using the method described by Maxwell et al. (1995). Saponin was determined spectrophotometrically using the method described by Makkar and Becker (1996). The method of Trease and Evans (1983) was used for the determination of flavonoids, anthraquinones, and polyphenols. The method by Bohn and Kocapai-Abyazan (1994) was used for the determination of tannin.

\subsection{Determination of Microbes and Aspergillus Counts}

The method of Abramson and Clear (1996) was used for aspergillus counts. Ten (10) gram samples were ground and thoroughly mixed with $90 \mathrm{ml}$ of sterile distilled water. Spore counting was performed by plate count technique on a selective medium for Aspergillus flavus after incubation for 7 days at $25^{\circ} \mathrm{C}$ using each suspension in a serial dilution from $10^{-1}$ up to $10^{-6}$ according to method. The count of Escherichia coli was performed on Violet Red Bile Agar (VRBA) incubated at $37^{\circ} \mathrm{C}$ for $48 \mathrm{hrs}$. Enumeration of Salmonella was performed on Salmonella Shigella Agar (SSA) incubated at $37^{\circ} \mathrm{C}$ for $48 \mathrm{hrs}$.

\subsection{Statistical Analysis}

Mean and Standard Deviation (SD) of the samples were determined using the statistical package for social sciences (SPSS) version 12 software package. Significance was accepted at 5\% probability level. All the data reported in the tables are average values of triplicate determinations.

\section{Results}

The results of the proximate analysis as shown in Table 1 shows Capsicum genus to have the highest moisture content $(11.16 \pm 0.06 \%)$ which was significantly $(p<0.05)$ higher than the moisture contents of all the other pepper. There was significant difference $(p<0.05)$ between Capsicum frutescens $(10.14 \pm 0.04 \%)$ and Capsicum annuum $(9.43 \pm 0.02 \%)$ with the former significantly higher than the later. Capsicum frutescens have the highest ash contents $(16.77 \pm 0.04 \%)$ which was significantly higher $(p<0.05)$ when compared to Capsicum genus $(10.78 \pm 0.04 \%)$ and Capsicum annuum $(9.78 \pm 0.04 \%)$. Ash contents of Capsicum genus was also significantly higher $(p<0.05)$ than 
Capsicum annuum when compared. Capsicum genus has the lowest crude protein value $(9.62 \pm 0.03 \%)$ which was significantly $(\mathrm{p}<0.05)$ lower than those of Capsicum frutescens $(11.97 \pm 0.05 \%)$ and Capsicum annuum (11.67 $\pm 0.03 \%)$. Also, Capsicum frutescens was significantly higher $(\mathrm{p}<0.05)$ than Capsicum annuum. The fat contents of Capsicum frutescens $(1.75 \pm 0.02 \%)$ was significantly higher $(p<0.05)$ than the fat contents of Capsicum genus $(0.41 \pm 0.02 \%)$ and Capsicum annuum $(0.35 \pm 0.03 \%)$. Also, Capsicum genus shows higher fat contents which was significantly $(\mathrm{p}<0.05)$ higher than the Capsicum annuum. The insoluble fibre contents of the Capsicum annuum $(13.22 \pm 0.04 \%)$ was the highest which was significantly $(\mathrm{p}<0.05)$ higher than the Capsicum genus $(8.71 \pm 0.02 \%)$ and Capsicum frutescens (1.02 $\pm 0.04 \%)$. There was significant difference $(\mathrm{p}<0.05)$ of Capsicum genus when compared to Capsicum frutescens. Capsicum frutescens has the lowest soluble fibre contents $(0.76 \pm 0.02 \%)$ which was significantly $(\mathrm{p}<0.05)$ lower than those of Capsicum annuum $(9.44 \pm 0.02 \%)$ and Capsicum genus $(6.44 \pm 0.02 \%)$. Capsicum annuum have the highest soluble fibre contents which was significantly $(p<0.05)$ higher than Capsicum genus. The carbohydrate content of Capsicum annuum $(66.98 \pm 0.05)$ was significantly $(p<0.05)$ higher than those of the other two pepper with Capsicum frutescens having the lowest carbohydrate contents $(58.81 \pm 0.04 \%)$.

The results of vitamin composition of Capsicum annuum, Capsicum genus, and Capsicum frutescens as shown in Table 2 shows that Capsicum annuum have the highest vitamin $\mathrm{C}$ content $(41.55 \pm 0.04 \%)$ which was significantly $(\mathrm{p}<0.05)$ higher than those of Capsicum genus $(27.13 \pm 0.05 \%)$ and Capsicum frutescens $(22.21 \pm 0.03 \%)$ with Capsicum frutescens having the lowest vitamin $\mathrm{C}$ content. Capsicum annuum shows the highest vitamin A content $(1.55 \pm 0.03 \%)$ which was significantly $(p<0.05)$ higher than that of all the other pepper. Capsicum annuum also has the highest vitamin $\mathrm{E}$ contents $(0.71 \pm 0.05 \%)$ which was significantly $(p<0.05)$ higher than that of Capsicum genus $(0.41 \pm 0.02 \%)$ and Capsicum frutescens $(0.35 \pm 0.03 \%)$ when compared. Also, Capsicum genus was significantly $(\mathrm{p}<0.05)$ different from Capsicum frutescens when compared. Capsicum annuum has the highest Niacin content which was significantly $(\mathrm{p}<0.05)$ higher than those of the Capsicum genus and Capsicum frutescens. However, there was no significant difference $(p>0.05)$ between the Niacin content of Capsicum genus and Capsicum frutescens. There was no significant difference $(p>0.05)$ of Capsicum annuum, Capsicum genus and Capsicum frutescens when compared. Capsicum annuum has the highest Folic acid value $(8.14 \pm 0.02 \%)$ which was significantly $(\mathrm{p}<0.05)$ higher than Capsicum genus $(6.49 \pm 0.02 \%)$ and Capsicum frutescens $(7.16 \pm 0.02 \%)$. Also, Capsicum frutescens was significantly $(p<0.05)$ higher than Capsicum genus when compared. The vitamin $\mathrm{K}$ content of Capsicum annuum $(6.68 \pm 0.05 \%)$ has the highest value which was significantly $\mathrm{p}<0.05$ ) different from Capsicum genus $(6.28 \pm 0.11 \%)$ and Capsicum frutescens $(5.81 \pm 0.04 \%)$ when compared.

The results of mineral composition of Capsicum annuum, Capsicum genus, and Capsicum frutescens as shown in Table 3 shows that Capsicum annuum has the highest calcium value $(134.35 \pm 1.24 \%)$ which was significantly $(p<0.05)$ higher than that of other pepper varieties, followed by Capsicum frutescens and Capsicum genus having the lowest calcium value $(104.18 \pm 0.15 \%)$ in this order. Capsicum annuum has the highest sodium content $(1.66 \pm 0.01 \%)$ which was significantly $(\mathrm{p}<0.05)$ higher than Capsicum frutescens $(1.17 \pm 0.02 \%)$ and Capsicum genus $(1.12 \pm 0.02 \%)$. However, there was no significant different $(\mathrm{p}>0.05)$ between Capsicum frutescens and Capsicum genus. Capsicum genus has the highest potassium content $(349.42 \pm 0.04 \%)$ which was significantly $(\mathrm{p}<0.05)$ higher than Capsicum annuum (324.21 $\pm 0.03 \%)$ and Capsicum frutescens $(331.32 \pm 0.02 \%)$. Comparison shows significant difference $(p<0.05)$ between Capsicum annuum and Capsicum frutescens. Capsicum annuum has the highest phosphorus value $(37.24 \pm 0.03 \%)$ which was significantly higher than that of other pepper varieties, followed by Capsicum frutescens and Capsicum genus having the lowest phosphorus value $(28.75 \pm 0.04 \%)$ in this order. Iron content shows that Capsicum annuum has the highest iron content $(139.24 \pm 0.05 \%)$ which was significantly $(\mathrm{p}<0.05)$ higher than that of Capsicum genus $(71.41 \pm 0.04 \%)$ and Capsicum frutescens $(67.16 \pm 0.04 \%)$. Comparison shows significant difference $(\mathrm{p}<0.05)$ between Capsicum genus and Capsicum frutescens. Capsicum annuum (26.92 $\pm 0.05 \%)$ contains significant $(\mathrm{p}<0.05)$ amounts of copper when compared with Capsicum genus $(18.22 \pm 0.07 \%)$ and Capsicum frutescens $(17.08 \pm 0.05 \%)$. Capsicum genus has the highest amount of cobalt content (13.27 \pm 0.09$)$ which was significantly higher than that of the other pepper varieties, with Capsicum frutescens having the lowest cobalt content $(4.38 \pm 0.06 \%)$. Capsicum annuum $(2.11 \pm 0.05 \%)$ contains significant $(\mathrm{p}<0.05)$ amounts of Zinc when compared with any of the pepper varieties. Comparison shows significant difference $(p<0.05)$ between Capsicum genus and Capsicum frutescens. Nickel content of Capsicum annuum $(2.11 \pm 0.05 \%)$ was significantly $(p<0.05)$ higher than that of the other pepper varieties, followed by Capsicum genus and Capsicum frutescens having the lowest Nickel content $(1.08 \pm 0.04 \%)$ in this order.

Results of phytochemical composition of Capsicum annuum, Capsicum genus, and Capsicum frutescens as shown in Table 4 shows that Capsicum annuum has the highest flavonoids content $(4.91 \pm 0.31 \%)$ which was significantly $(\mathrm{p}<0.05)$ different from Capsicum frutescens but not significantly $(\mathrm{p}>0.05)$ different when compared to Capsicum genus. However, there was no significant difference $(p>0.05)$ between Capsicum genus and Capsicum frutescens. Tannin content of the pepper varieties shows no significant difference $(p>0.05)$. Alkaloid content of Capsicum genus $(3.02 \pm 0.02 \%)$ was significantly 
different $(p<0.05)$ from that of the other pepper varieties. However, there was no significant difference $(p>0.05)$ between Capsicum annuum and Capsicum frutescens. Capsicum frutescens $(2.81 \pm 0.11 \%)$ contains significantly $(p<0.05)$ high amounts of anthraquinones when compared to other pepper varieties. Comparison shows significant difference $(\mathrm{p}<0.05)$ between Capsicum genus and Capsicum annuum. The phenolic content of Capsicum annuum $(3.00 \pm 0.12 \%)$ has the highest phenolic content which was significantly $(\mathrm{p}<0.05)$ different from Capsicum genus $(5.54 \pm 0.27 \%)$ and Capsicum frutescens $(2.35 \pm 0.05 \%)$. Also, Capsicum genus was significantly $(p<0.05)$ different from Capsicum frutescens. The saponin content of Capsicum annuum was significantly $(p<0.05)$ higher than that of the other pepper varieties, followed by Capsicum genus and Capsicum frutescens having the lowest saponin content $(1.94 \pm 0.15 \%)$. There was no significant difference $(\mathrm{p}>0.05)$ between Capsicum genus and Capsicum frutescens. Capsicum genus (1.02 $\pm 0.04 \%)$ was significantly different $(\mathrm{p}<0.05)$ from both Capsicum annuum $(0.55 \pm 0.03 \%)$ and Capsicum frutescens
$(0.53 \pm 0.04 \%)$ in its glycosides content. However, there was no significant difference $(\mathrm{p}>0.05)$ between Capsicum annuum and Capsicum frutescens. Terpenoids content shows that Capsicum annuum $(3.25 \pm 0.11 \%)$ has the highest terpenoids content which was significantly different $(\mathrm{p}<0.05)$ from the other pepper varieties. Comparison shows significant difference $(\mathrm{p}<0.05)$ between Capsicum frutescens and Capsicum genus. Limonoids content of Capsicum annuum $(0.57 \pm 0.05 \%)$ was significantly different $(\mathrm{p}<0.05)$ from Capsicum genus $(0.74 \pm 0.02 \%)$. However, Capsicum frutescens did not show any limonoid content. Carotenoids content shows that Capsicum frutescens $(1.67 \pm 0.04 \%)$ was significantly different $(p<0.05)$ from the other pepper varieties. There was no significant different ( $>0.05$ ) between Capsicum genus and Capsicum annuum.

Results of microbiological quality of Capsicum annuum, Capsicum genus, and Capsicum frutescens as shown in Table 5 shows that Escherichia coli and salmonella species were absent from the different pepper varieties. The total viable count, Aspergillus flavus, and Staphylococcus species were $<1000,<10$ and $<100$ respectively.

Table 1. Proximate composition of Capsicum annuum, Capsicum genus, and Capsicum frutescens

\begin{tabular}{|c|c|c|c|c|c|c|c|}
\hline Pepper varieties & $\%$ moisture & $\%$ Protein & $\%$ Fat & $\%$ Ash & \% Insoluble & \%soluble fire & $\%$ Carbohydrate \\
\hline $\begin{array}{l}\text { Capsicum annuum } \\
\text { (Drum pepper) }\end{array}$ & $9.43 \pm 0.02$ & $11.67 \pm 0.03$ & $1.75 \pm 0.02$ & $9.78 \pm 0.04$ & $13.22 \pm 0.04$ & $9.44 \pm 0.02$ & $66.98 \pm 0.05$ \\
\hline $\begin{array}{l}\text { Capsicum genus } \\
\text { (Long chili pepper) }\end{array}$ & $11.16 \pm 0.06^{*}$ & $9.62 \pm 0.03 *$ & $0.41 \pm 0.02 *$ & $10.78 \pm 0.04 *$ & $8.71 \pm 0.02 *$ & $6.44 \pm 0.02 *$ & $68.28 \pm 0.11^{*}$ \\
\hline $\begin{array}{l}\text { Capsicum frutescens } \\
\text { (Small chili pepper) }\end{array}$ & $10.14 \pm 0.04^{*, \mathrm{a}}$ & $11.97 \pm 0.5^{\mathrm{a}}$ & $0.35 \pm 0.03 *$ & $16.677 \pm 0.04^{*, a \mathrm{a}}$ & $1.02 \pm 0.04^{*, a}$ & $0.76 \pm 0.02^{*, \mathrm{a}}$ & $58.81 \pm 0 .^{\text {a }}$ \\
\hline
\end{tabular}

Values are expressed as mean \pm SEMD, $n=3$

*: Significantly different from Drum pepper at $\mathrm{P}<0.05$

a: Significantly different from Long chili pepper at $\mathrm{P}<0.05$

Table 2. Vitamins composition of Capsicum annuum, Capsicum genus, and Capsicum frutescens

\begin{tabular}{|c|c|c|c|c|c|c|c|}
\hline Pepper varieties & $\begin{array}{l}\text { Vit C } \\
\mathrm{mg} / 100 \mathrm{~g}\end{array}$ & $\begin{array}{l}\text { Vit A } \\
\mu \mathrm{g} / 100 \mathrm{~g}\end{array}$ & $\begin{array}{l}\text { Vit E } \\
\mathrm{mg} / 100 \mathrm{~g}\end{array}$ & $\begin{array}{l}\text { Niacin } \\
\mathrm{mg} / \mathbf{1 0 0 g}\end{array}$ & $\begin{array}{l}\text { Vit B6 } \\
\mathrm{mg} / 100 \mathrm{~g}\end{array}$ & $\begin{array}{l}\text { Folic acid } \\
\mu \mathrm{g} / 100 \mathrm{~g}\end{array}$ & $\begin{array}{l}\text { Vit } \mathrm{K} \\
\mu \mathrm{g} / \mathbf{1 0 0 g}\end{array}$ \\
\hline $\begin{array}{l}\text { Capsicum annuum (Drum } \\
\text { pepper) }\end{array}$ & $47.55 \pm 0.44$ & $1.55 \pm 0.03$ & $0.71 \pm 0.05$ & $0.68 \pm 0.04$ & $0.12 \pm 0.01$ & $8.14 \pm 0.02$ & $6.68 \pm 0.05$ \\
\hline $\begin{array}{l}\text { Capsicum genus (Long chili } \\
\text { pepper) }\end{array}$ & $27.13 \pm 0.05 *$ & $1.26 \pm 0.03 *$ & $0.41 \pm 0.02 *$ & $0.58 \pm 0.04 *$ & $0.11 \pm 0.01 *$ & $6.44 \pm 0.02 *$ & $6.28 \pm 0.11^{*}$ \\
\hline $\begin{array}{l}\text { Capsicum frutescens (Small } \\
\text { chili pepper) }\end{array}$ & $22.21 \pm 0.02^{*, \mathrm{a}}$ & $1.07 \pm 0.05^{*, \mathrm{a}}$ & $0.35 \pm 0.03 *$ & $0.47 \pm 0.04 *$ & $0.10 \pm 0.01$ & $7.16 \pm 0.02^{*, \mathrm{a}}$ & $5.81 \pm 0.04^{*, \mathrm{a}}$ \\
\hline
\end{tabular}

Values are expressed as mean \pm SEMD, $n=3$

*: Significantly different from Drum pepper at $\mathrm{P}<0.05$

a: Significantly different from Long chili pepper at $\mathrm{P}<0.05$

Table 3. Minerals Composition of Capsicum annuum, Capsicum genus, and Capsicum frutescens

\begin{tabular}{|c|c|c|c|c|c|c|c|c|c|c|}
\hline Pepper varieties & $\begin{array}{l}\mathrm{Ca} \\
(\mathrm{mg} / 100 \mathrm{~g})\end{array}$ & $\begin{array}{l}\mathrm{Na} \\
(\mathrm{mg} / \mathbf{1 0 0 g})\end{array}$ & $\begin{array}{l}\mathrm{K} \\
(\mathrm{mg} / \mathbf{1 0 0 g})\end{array}$ & $\begin{array}{l}\mathrm{Mg} \\
(\mathrm{mg} / \mathbf{1 0 0 g})\end{array}$ & $\begin{array}{l}P \\
(\mathrm{mg} / \mathbf{1 0 0 g}) \\
\end{array}$ & $\begin{array}{l}\text { Fe } \\
(\mathrm{mg} / 100 \mathrm{~g})\end{array}$ & $\begin{array}{l}\mathrm{Cu} \\
(\mathrm{PPM}) \\
\end{array}$ & $\begin{array}{l}\mathrm{Zn} \\
\text { (PPM) }\end{array}$ & $\begin{array}{l}\text { Co } \\
\text { (PPM) }\end{array}$ & $\begin{array}{l}\text { Nl } \\
\text { (PPM) }\end{array}$ \\
\hline $\begin{array}{l}\text { Capsicum annuum } \\
\text { (Drum pepper) }\end{array}$ & $134.35 \pm 1.24$ & $1.66 \pm 0.01$ & $324.21 \pm 0.05$ & $\begin{array}{l}328.42 \pm 0.0 \\
5\end{array}$ & $37.24 \pm 0.03$ & $\begin{array}{l}139.24 \pm 0.0 \\
5\end{array}$ & $\begin{array}{l}26.92 \pm 0 \\
05\end{array}$ & $\begin{array}{l}244.12 \pm 2 \\
.55\end{array}$ & $6.4 \pm 0.06$ & $2.11 \pm 0.05$ \\
\hline $\begin{array}{l}\text { Capsicum genus (Long } \\
\text { chili pepper) }\end{array}$ & $10.4 .18 \pm 0.15 *$ & $1.12 \pm 0.02 *$ & $349.42 \pm 0.04 *$ & $\begin{array}{l}274.88 \pm 0.0 \\
2 *\end{array}$ & $\begin{array}{l}28.75 \pm 0.04 \\
*\end{array}$ & $\begin{array}{l}71.41 \pm Q .04 \\
*\end{array}$ & $\begin{array}{l}18.22 \pm 0 \\
01 *\end{array}$ & $\begin{array}{l}38.02 \pm 0 \\
05^{*}\end{array}$ & $\begin{array}{l}13.27 \pm 0 \\
09 *\end{array}$ & $\begin{array}{l}1.25 \pm 0.05 \\
*\end{array}$ \\
\hline $\begin{array}{l}\text { Capsicum frutescens } \\
\text { (Small chili pepper) }\end{array}$ & $106.27 \pm 0.07^{*, \mathrm{a}}$ & $1.17 \pm 0.02 *$ & $\underset{, \mathrm{a}}{331.32 \pm 0.02 *}$ & $\begin{array}{l}236.72 \pm 0.0 \\
2 * \text {, a }\end{array}$ & $\begin{array}{l}31.44 \pm 0.05 \\
* \mathrm{a}\end{array}$ & $\begin{array}{l}67.16 \pm 0.04 \\
*, \mathrm{a}\end{array}$ & $\begin{array}{l}17.08 \pm 0 . \\
05^{*, a}\end{array}$ & $\begin{array}{l}32.18 \pm 0.0 \\
8 *, \mathrm{a}\end{array}$ & $\begin{array}{l}4.38 \pm 0.0 \\
6^{*, \mathrm{a}}\end{array}$ & $\begin{array}{l}1.08 \pm 0.04 \\
*, \mathrm{a}\end{array}$ \\
\hline
\end{tabular}

Values are expressed as mean \pm SEMD, $n=3$

*: Significantly different from drum pepper at $\mathrm{P}<0.05$

a: Significantly different from long chili pepper at $\mathrm{P}<0.05$ 
Table 4. Phytochemical Properties of Capsicum annuum, Capsicum genus, and Capsicum frutescens

\begin{tabular}{|c|c|c|c|c|c|c|c|c|c|c|}
\hline $\begin{array}{l}\text { Pepper } \\
\text { Varieties }\end{array}$ & $\begin{array}{l}\text { Parameter } \\
\% \\
\text { Tannins } \\
\end{array}$ & $\begin{array}{l}\text { tested } \\
\% \\
\text { Flavonoid }\end{array}$ & $\begin{array}{l}\% \\
\text { Alkaloids }\end{array}$ & $\begin{array}{l}\% \\
\text { Anthraquinones }\end{array}$ & \% Phenolic & \% Saponin & $\begin{array}{l}\% \\
\text { Glycosides }\end{array}$ & $\begin{array}{l}\% \\
\text { Terpenoids }\end{array}$ & $\begin{array}{l}\text { \% } \\
\text { Limonoids }\end{array}$ & $\begin{array}{l}\% \\
\text { Carotenoids } \\
\end{array}$ \\
\hline $\begin{array}{l}\text { Capsicum } \\
\text { annuum } \\
\text { (Drum } \\
\text { Pepper) }\end{array}$ & $1.44 \pm 0.22$ & $4.91 \pm 0.31$ & $1.55 \pm 0.11$ & $1.22 \pm 0.05$ & $3.00 \pm 0.12$ & $3.76 \pm 0.13$ & $0.55 \pm 0.03$ & $3.25 \pm 0.11$ & $0.57 \pm 0.05$ & $1.97 \pm 0.06$ \\
\hline $\begin{array}{l}\text { Capsicum } \\
\text { genus } \\
\text { (Long } \\
\text { Chili } \\
\text { Pepper) }\end{array}$ & $1.21 \pm 0.12$ & $3.87 \pm 0.41$ & $3.02 \pm 0.02 *$ & $1.71 \pm 0.05 *$ & $5.54 \pm 0.27 *$ & $2.18 \pm 0.04 *$ & $1.02 \pm 0.04 *$ & $1.43 \pm 0.02 *$ & $0.74 \pm 0.02 *$ & $0.21 \pm 0.04 *$ \\
\hline $\begin{array}{l}\text { Capsicum } \\
\text { frutescens } \\
\text { (Small } \\
\text { Chili } \\
\text { Pepper) }\end{array}$ & $0.98 \pm 0.12$ & $2.43 \pm 0.34 *$ & $1.09 \pm 0.02^{\mathrm{a}}$ & $2.81 \pm 0.11^{*, \mathrm{a}}$ & $2.35 \pm 0.05^{*, \mathrm{a}}$ & $1.94 \pm 0.15^{*}$ & $0.53 \pm 0.04^{\mathrm{a}}$ & $2.25 \pm 0.12^{* a}$ & $0.00 \pm 0.00 * a$ & $1.67 \pm 0.04 *^{\mathrm{a}}$ \\
\hline
\end{tabular}

Values are expressed as mean

* Significantly different from drum pepper at $\mathrm{P}<0.05$

a: Significantly different from long chili pepper at $\mathrm{P}<0.05$

TABLE 5. Microbiological Quality of Capsicum annuum, Capsicum genus, and Capsicum frutescens

\begin{tabular}{|c|c|c|c|c|c|}
\hline Pepper varieties & Coliform (E.coli) & TVC (cfu/mg) & Salmonella spp & Aspergillus flavus & Staphylococcus Spp \\
\hline $\begin{array}{l}\text { Capsicum annuum } \\
\text { (Drum pepper) }\end{array}$ & 0 & $<1000$ & 0 & $<10$ & $<100$ \\
\hline $\begin{array}{l}\text { Capsicum genus } \\
\text { (Long chili pepper) }\end{array}$ & 0 & $<1000$ & 0 & $<10$ & $<100$ \\
\hline $\begin{array}{l}\text { Capsicum frutescens } \\
\text { (Small chili pepper) }\end{array}$ & 0 & $<1000$ & 0 & $<10$ & $<100$ \\
\hline
\end{tabular}

Values are expressed as mean \pm SEMD, $\mathrm{n}=3$

\section{Discussion}

Capsicum genus had the highest moisture content of $11.16 \%$ followed by Capsicum frutescens with a value of $10.14 \%$ while Capsicum annuum had the least value of $9.43 \%$ showing significant difference $(p<0.05)$ from the rest. The high levels of moisture in all the samples investigated suggests that the pepper would not be store for long without spoilage since high water activity could enhance microbial action bringing about food spoilage. Hence, dehydrating pepper increases the storage-life or shelf-life of peppers. This result corresponds with the findings of Esayas et al. (2011).

Capsicum annuum showed significantly higher protein content $(\mathrm{p}<0.05)$ compared to the other pepper varieties while Capsicum genus had the least protein content. In general pepper needs to be combined with other foods of high protein value in order to meet the protein requirements of individuals (Ejoh et al., 1996). This justifies the non-use of these pepper varieties as sole ingredients to provide the basic protein need. Usually, crude protein in pepper needs supplementation with other protein condiments.

Total lipids for the samples varied with Capsicum annuum showing more appreciable values than Capsicum genus and Capsicum frutescens. Generally, the low values in some of the pepper varieties agree with the findings of many authors that pepper are poor sources of lipids (Gloria et al., 2010; Ejoh et al., 1996).

The ash contents of all the pepper varieties are relatively high with Capsicum frutescens having the highest value of $16.77 \%$ and Capsicum annuum having the least value of $9.78 \%$. These values although high agree with the reported findings made by other researchers (Esayas et al., 2011; Ejoh et al., 1996). The high ash contents suggest the availability of minerals in the samples which is subsequently confirmed by the considerably high content of sodium $(1.66 \mathrm{mg} / \mathrm{L})$, calcium $(134.35 \mathrm{mg} / \mathrm{L})$, and Phosphorus $(37.24 \mathrm{mg} / \mathrm{L})$ in Capsicum frutescens.

The insoluble and soluble fibre of the pepper varieties varied with the Capsicum annuum showing more appreciable values than the Capsicum genus and Capsicum frutescens. Esayas et al. (2011) reported that percentage insoluble fibre content of these pepper varieties ranged from $1.00 \pm 0.6$ to $7.3 \pm 2.2 \%$. Insoluble fibre is essential in enhancing digestion and bowel movement (Papas et al., 2004). Soluble fibre lowers blood cholesterol and glucose level.

High levels of carbohydrate were found in Capsicum genus while Capsicum frutescens showed relatively low values $(p>0.05)$. However, these carbohydrates present, even when high in value might not be nutritionally assessable since most of them are bound to remain undigested in the body (Gloria et al., 2010).

The level of vitamin $\mathrm{C}$ in the samples can make 
significant contribution to lowering serum triglyceride concentration. Capsicum annuum can contribute most significantly among the pepper varieties, while Capsicum frutescens can contribute the lowest value. Their contribution to vitamin $\mathrm{E}$, Niacin, Vitamin $\mathrm{B}_{6}$ and vitamin A will be insignificant, as their values of these nutrients were negligible. Comparably, Capsicum annuum had the highest value of vitamin $\mathrm{E}$, Niacin, Vitamin $\mathrm{B}_{6}$ and vitamin A. The levels of vitamin $\mathrm{C}$ and vitamin $\mathrm{K}$ coupled with the presence of folic acid in the pepper qualify them as good sources of antioxidant which prevent or remove free radicals from the body, thereby preventing tumor growth. Antioxidants such as ascorbic acid (vitamin C) have been associated with prevention of nutritionally associated diseases such as cancers, diabetes, obesity (Hunt et al., 1980), and the Capsicum annuum was high in these antioxidants, hence it has health-promoting benefits.

The calcium, sodium, magnesium, phosphorus, iron, copper, zinc and nickel content of Capsicum annuum in this study were higher than the other pepper varieties. The Capsicum annuum were good sources of calcium, magnesium, sodium, phosphorus, and can make some contribution to these micronutrient intakes, though it is normally used in small quantities in cooking. Sodium is an electrolyte which functions in the control of fluid balance in the body, controls extracellular fluid, and is essential for osmosis. It is important in maintaining acid-base balance in the body and participates in the transmission of nerve impulses essential for normal function (Onwaka, 2005). Calcium, in combination with phosphorus, is a component of bones and teeth to give strength and hardness. It is needed for normal nerve and muscle action, blood clotting, heart function and cell metabolism (Neiman et al., 1992), hence the Capsicum annuum have health promoting properties. Also, the Capsicum annuum can serve as sources of meeting part of the daily requirements for zinc and iron.

The results of phytochemical showed that flavonoids, saponins, tannins, terpenoids were higher in Capsicum annuum. The presence of tannins, flavonoids, alkaloids, anthraquinones, phenolic compounds, saponins, glycosides, terpenoids, carotenoids is an indication of medicinal potentials of the pepper varieties particularly Capsicum annuum. Flavonoids are free radical scavengers, super antioxidants which prevent oxidative cell damage and have strong anti-cancer activity (Salah et al., 1995). Alkaloids are efficient therapeutic substance. Pure isolated alkaloids are used as basic medicinal agent because of their bacterial properties (Stray, 1998). Glycosides are important medicinally due to their action on the heart, and tannins play an important role in preventing bacteria from adhering to the walls of the urinary tract, thereby preventing urinary tract infection. Hence, Capsicum annuum, Capsicum genus, and Capsicum frutescens possess medicinal properties. Escherichia coli and salmonella were absent in all the pepper varieties. Also, the presence of staphylococcus specie and Aspergillus specie in the pepper varieties were less than $100 \%$ and $10 \%$.

\section{Conclusion}

The present study has shown the phytochemical composition, vitamins composition, minerals composition, proximate composition and microbiological quality of capsicum annuum (Drum pepper), capsicum genus (Long chili pepper), and capsicum frutescens (Small chili pepper). The pepper varieties contain substantial quantities of minerals, vitamins, and phytochemicals. Comparatively, the average nutritive value of Capsicum annuum is superior to those of the other pepper varieties analyzed. The findings suggest that all the three pepper contains appreciable amounts of nutrients; however it is observed that no one particular pepper is rich in all nutrients, hence the need to consume the pepper as combinations with themselves.

\section{References}

[1] Abramson, D. \& Clear, R. M. (1996). A convenient method for assessing mycotoxin production in cultures of Aspergillus and Penicillia. Journal of Food Protection, 59:642-644.

[2] Adenlyl, M. 0. (1977). Status of Plant Protection in the Operation Feed the Nation Programmes. Presidential Address delivered at its 7th Annual Conference at Institute of Agriculture Research and Technology (IART) Moore Plantation in Ibadan, p. 10-17.

[3] Agbola, S. D (1980). The Role of Nigeria Stored Product Research Institute in Nigeria March toward Self- sufficiency in Food. NSPRT Occasional Paper Series, 117: 25-29.

[4] AQAC (1990). Association of Official Analytical Chemist. Official Method of Analyst (15th Ed), Washington DC, USA.

[5] Bendich A. (2000). The potential for dietary supplements to reduce premenstrual syndrome (PMS) symptoms. Journal of American Nutrition, 19(1): 3-12.

[6] Bohn, B. A., Kocai-Abyaza, R. (1994). Flavonoid and condensed from leaves of Hawaiinvacciniumratulation and $\mathrm{v}$ calycinum. Pacific Science, 48:458-463.

[7] Bosland, P. W. (1993). Breeding for quality in Capsicum.Capsicum and Eggplant Newsletter, 12: 25-31.

[8] Esayas K., Shimelis A., Ashebir F., Tilahun B., and Gulelat D., (2011). Proximate composition, Mineral content, and Antinutritional factors of some capsicum (Capsicum annum) varieties grown in Ethiopia. Journal of the Korean society of Food Science and Nutrition, 37(8): 1084-1089.

[9] Gloria A., Oyelola B, Adenika T., Anthony J., (2010). Comparative analysis of the chemical composition of three Spices. Journal of the Korean society of Food Science and Nutrition, 37(8): 1090-1095.

[10] Howard, L. R., Talcott, S. T., Brenes, C. H., \&Villalon, B. (2000). Changes in phytochemical and antioxidant activity of selected pepper cultivars (Capsicum sp.) as influenced by maturity. Journal of Agriculture and Food Chemistry, 48:1713-1720. 
[11] Hunt, S., Goff, J., and Holbrook J. (1980). Nutrition principles and chemical practices. John Wiley andSons. New York, pp: 4952.

[12] IVACG. (1992). Reprints of Selected Methods for Analysis of vitamin A and carotenoids in nutrition surveys. Washington D.C. The nutrition Foundation, pp 16-18.

[13] Makkar, H. P. S., Becker, K. (1996). Nutritional value and antinutritional components of whole and ethanol extracted moringaoleifera. Animal Feed Science Technology, 63:211-238

[14] Markus, F., H.G. Daood, J. Kapitany and P.A. Biacs. 1999. Change in the carotenoid andantioxidant content of spice red pepper (paprika) as a function of ripening andsome technological factors. Journal of Agriculture and Food Chemistry, 47: 100-107.

[15] Maxwell, A., Seepersani, M. P., Mooton, D. R. (1995). 3, 6-Amino spirosoane steroid alkaloids from solamintriste. Journal of Natural Product, 58 (4):821-825.

[16] Nkam, I. \&Gbenyi, D. I. (2001). The Effects of Millet and Sorg bum on the Residure. Phytate and Polypheno in "Dakura" a Nigeria Cereal/Legume Snack Food. Nigerian Tropical Journal of Agriculture, 3, 270-271.

[17] Okwu, D. E. \&Ekeke, 0. (2003). Phytochemical Screening and Mineral Composition of Chewing Stick in South Eastern Nigeria. Gobal Journal of Pure Applied Science, 6: $58-61$.
[18] Onwuka, G. I. (2005). Food analysis and instrumentation theory and practice. 1st ed. Apex Book limited, Lagos. Pp: 63-120.

[19] Oyeleke, A. O. (1984). Outline of Food Analysis. Ahmadu Bello University Press, Zaria, Nigeria.

[20] Papas M., Giorannuli E., \&Platze E. (2004). Fibre from fruit and colorectal Neoplasia. Journal of cancer Epidemiology Biomarker and prevention, 13: 1267-1270.

[21] Salah, W., Miller, N., Pagauga, G., Tybury, G., Bolwell, E., Rice, E., \& Evans, C. (1995). Flavonoids as scavenger of aqueous phase radicals and chain breaking antioxidants. Biochemistry Journal, 2:239-346.

[22] Stray, F. (1998). The natural guide to medicinal herbs and plants. Tiger Book International, London, pp: 12-16.

[23] Trease, G. E., \& Evans, W. C. (1983). Pharmacognosy. $14^{\text {th }}$ Edition. Brown Publication, London.

[24] Smolin, F.; Klein, E.; Levy \& Bon-Shacken D. (2007). Preliminary Phytochernical Screening and Invitro Antioxidant Properties of MorigaOliefera. Journal of Biochemistry, 45(5): 665-680.

[25] Yoshimura, M., Eakahasi, H., \& Nakanishi. (1991). Role of sodium, potassium, calcium, and magnesium on blood pressure regulation. Japan Journal of Nutrition, 49: 53- 62. 